Article

\title{
Interactions between the Intrinsically Disordered Regions of hnRNP-A2 and TDP-43 Accelerate TDP-43's Conformational Transition
}

\author{
Wan-Chin Chiang ${ }^{1}$, Ming-Hsuan Lee ${ }^{1}$, Tsai-Chen Chen ${ }^{1}$ and Jie-rong Huang ${ }^{1,2,3, * \mathbb{D}}$ \\ 1 Institute of Biochemistry and Molecular Biology, National Yang-Ming University, No. 155 Section 2, \\ Li-Nong Street, Taipei 11221, Taiwan; cmiyc777@gmail.com (W.-C.C.); 1km551200@gmail.com (M.-H.L.); \\ hazelnut.chen.scu@gmail.com (T.-C.C.) \\ 2 Institute of Biomedical Informatics, National Yang-Ming University, No. 155 Section 2, Li-Nong Street, \\ Taipei 11221, Taiwan \\ 3 Department of Life Sciences and Institute of Genome Sciences, National Yang-Ming University, \\ No. 155 Section 2, Li-Nong Street, Taipei 11221, Taiwan \\ * Correspondence: jierongh@ym.edu.tw
}

Received: 28 July 2020; Accepted: 15 August 2020; Published: 18 August 2020

\begin{abstract}
Most biological functions involve protein-protein interactions. Our understanding of these interactions is based mainly on those of structured proteins, because encounters between intrinsically disordered proteins (IDPs) or proteins with intrinsically disordered regions (IDRs) are much less studied, regardless of the fact that more than half eukaryotic proteins contain IDRs. RNA-binding proteins (RBPs) are a large family whose members almost all have IDRs in addition to RNA binding domains. These IDRs, having low sequence similarity, interact, but structural details on these interactions are still lacking. Here, using the IDRs of two RBPs (hnRNA-A2 and TDP-43) as a model, we demonstrate that the rate at which TDP-43's IDR undergoes the neurodegenerative disease related $\alpha$-helix-to- $\beta$-sheet transition increases in relation to the amount of hnRNP-A2's IDR that is present. There are more than 1500 RBPs in human cells and most of them have IDRs. RBPs often join the same complexes to regulate genes. In addition to the structured RNA-recognition motifs, our study demonstrates a general mechanism through which RBPs may regulate each other's functions through their IDRs.
\end{abstract}

Keywords: intrinsically disordered protein; liquid-liquid phase separation; membraneless organelle; NMR spectroscopy

\section{Introduction}

Protein-protein interactions mediate the functions of life [1]. The atomic details of the quaternary structure of interacting proteins, obtained by X-ray crystallography [2], NMR spectroscopy [3,4], or cryogenic electron microscopy (cryo-EM) [5-8], provide snapshots of how they work. Although most of the binding events reported to date involve folded domains, interactions between or with intrinsically disordered regions (IDRs, present in more than half of eukaryotic proteins $[9,10]$ ) are also important in many biological reactions: An IDR can contact its folded partner by folding upon binding [11,12]; current literature suggests that it is also common for IDRs to bind "fuzzily" to their folded partners without adapting a fixed conformation [13-15]. There have only been a few reports on how two IDRs from different proteins interact [16-18]. This gap in our understanding of protein-protein interaction networks can be filled by discovering new interaction modes between IDRs.

Almost all RNA-binding proteins (RBPs) have IDRs [19-21]. While RBPs are at the core of post-transcriptional gene regulation, the roles of their IDRs are only now coming to light. Studies show 
that some IDRs drive the location of the entire protein into biomolecular condensates (stress or RNA granules) via liquid-liquid phase separation (LLPS) [22-26] and that misregulation of condensate formation is pathogenic $[27,28]$. The IDRs of RBPs have also been shown in a few cases to interact with the IDRs of other proteins [29-31]. Overall, however, the roles of IDRs in this large (1500+ members [32]) protein family remain largely unexplored. Here, we demonstrate a new interaction mode, whereby the IDR of one RBP accelerates the aggregation of another RBP's IDR. Although the interactions between the IDRs of TDP-43 and hnRNP-A2 and their functional importance have been reported previously [33-35], molecular details of the effects of the two IDRs on each other have remained elusive (Figure 1C). We show here that the amount of hnRNPA2 determines the rates of $\alpha$-to- $\beta$ structural transition of TDP-43.

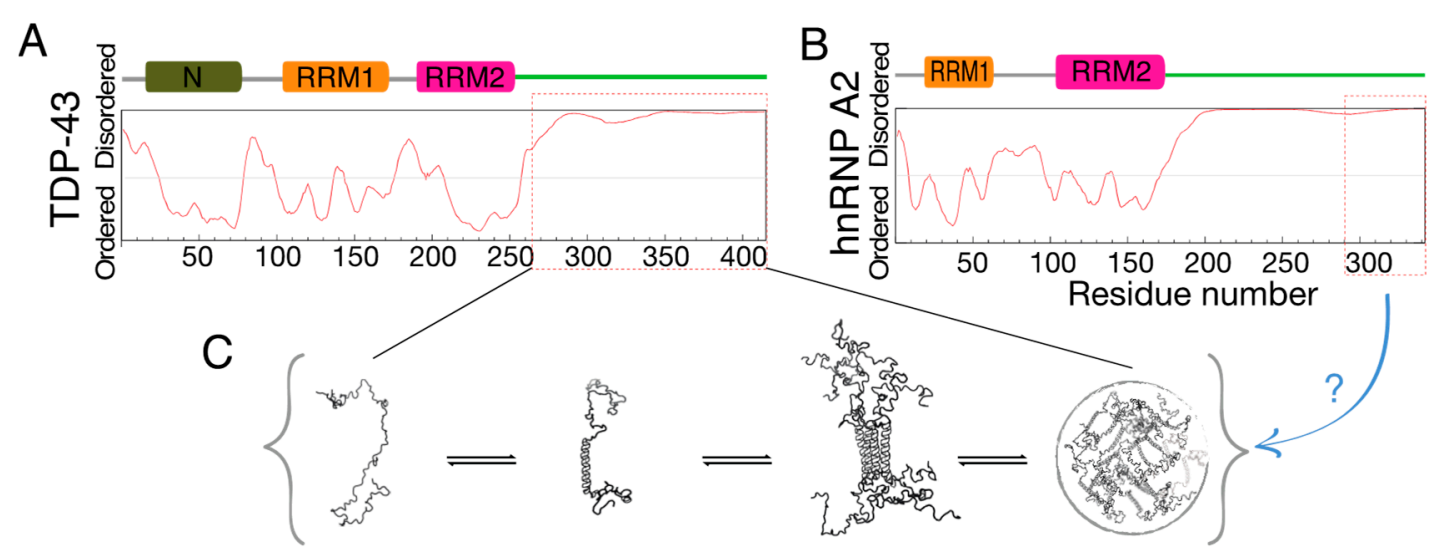

Figure 1. Schematic illustration of the intrinsically disordered regions (IDRs) of TDP-43 and hnRNP-A2 in this study. (A,B) The domains of (A) TDP-43 and (B) hnRNP-A2. The level of protein disorder was predicted using the PONDR VSL2 algorithm [36]. The fragments used in this study are indicated with red-dashed lines. (C) Schematic representation of the $\alpha$-helical, self-association, and liquid-liquid phase separation propensities of TDP-43 reported in previous publications [37-39]. The molecular details of the effects of hnRNP-A2 remain elusive.

\section{Results and Discussion}

TDP-43's intrinsically disordered C-terminal domain is responsible for RNA splicing inhibition, and this function is reduced by its interaction with hnRNP-A2 [33]. The regions of the two proteins involved in their interaction were identified by co-immunoprecipitation, specifically, the interaction was confirmed by observing a disruption of the supershift in electrophoretic mobility shift assays of synthesized peptides corresponding to specific regions of the two proteins [34,35]. Although minimum fragments of residues 321-366 from TDP-43 and residues 288-341 from hnRNP A2 were identified, there was no evidence of direct interactions (e.g., from GST pull-down assays), indicating that the binding is probably weak and transient. This is consistent with evidence of a weak interaction from intermolecular paramagnetic relaxation enhancement NMR measurements (which probe transient interactions) [40]. In the present study, no significant changes were observed in the chemical shifts of the $20 \mu \mathrm{M}{ }^{15} \mathrm{~N}$-labeled IDR of TDP-43 (TDP-43266-414; NMR-active) when it was mixed with a $20 \mu \mathrm{M}$ minimum fragment of ${ }^{14} \mathrm{~N}$ hnRNP-A2 (hnRNP-A2 ${ }^{288-341}$; NMR-inactive) and vice versa (Figure 2A,B). The fact that the summed circular dichroism (CD) spectra of hnRNP-A2288-341 and TDP-43 $3^{266-414}$ (both $20 \mu \mathrm{M}$ ) alone overlap closely with the spectrum of the mixed sample (Figure 2C), indicates that there are no changes in secondary structure upon mixing. Quantitative analysis of the experimental data (Figure 2D, left) and the summed CD curves (Figure 2D, right) yielded similar secondary structure contents. 

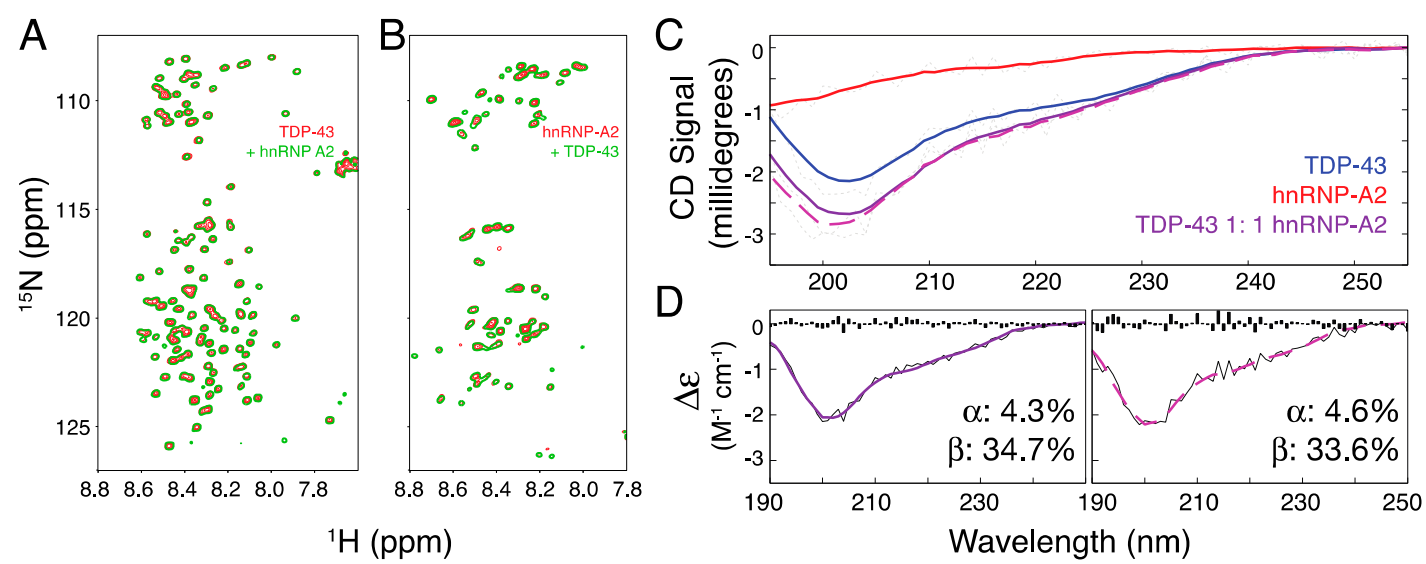

Figure 2. The interaction between the intrinsically disordered regions (IDRs) of TDP-43 and hnRNP-A2. (A) Overlaid NMR HSQC spectra of $20 \mu \mathrm{M}^{15} \mathrm{~N}$ TDP-43 ${ }^{266-414}$ alone (red) and in the presence of $20 \mu \mathrm{M}$ ${ }^{14} \mathrm{~N}-h n R N P-A 2^{288-341}$ (green). (B) Overlaid NMR HSQC spectra of $20 \mu \mathrm{M}^{15} \mathrm{~N}$ - hnRNP-A2 ${ }^{288-341}$ alone (red) and in the presence of $20 \mu \mathrm{M}^{14} \mathrm{~N}-\mathrm{TDP}-43^{266-414}$ (green). (C) Circular dichroism spectra of $20 \mu \mathrm{M}$ TDP-43 266-414 (blue), hnRNP-A2 ${ }^{288-341}$ (red), and a one-to-one mixture of the two (purple) overlaid on the summed spectra of the two proteins alone (broken purple line). (D) Fits using BeStSel [41,42] of the mixture (left panel) and numerically summed TDP-43/hnRNP-A2 spectra (right) and the proportion of secondary structure components obtained. The residuals of the fits are shown as black bars.

Although there were no significant changes initially in the mixture spectra, the intensity of the cross-peaks from residues 266-277 and $~ 314-340$ in the spectrum of ${ }^{15} \mathrm{~N}$-labeled TDP-43 ${ }^{266-414}$ (Figure 3A) decreased to the noise level within $9 \mathrm{~h}$ in the presence of hnRNP-A2 288-341 (Figure 3D). No such changes were observed for the mixture of ${ }^{15} \mathrm{~N}$-labeled hnRNP-A2 ${ }^{288-341}$ with ${ }^{14} \mathrm{~N}$-labeled TDP-43 $3^{266-414}$ (Figure 3B). Many peaks from residues $~ 340-350$ also have distorted shapes (see peak assignments in Figure 3A). The peaks from these residues also decrease over time in the spectra of TDP-43 $3^{266-414}$ alone, but more slowly (Figure 3C,E). Comparing Figure 3D,F shows that the relative decrease after $9 \mathrm{~h}$ in the mixture sample is only observed after $22 \mathrm{~h}$ for TDP-43 ${ }^{266-414}$ alone. The residues of which the corresponding peaks decrease significantly in intensity are clustered in two regions in the primary sequence (Figure 3G), including the previously identified $\alpha$-helical region (residues 314-340) [37-39]. Because some of the lost signals originate from the $\alpha$-helical region, this suggests that the time-dependent transition involves a change in secondary structure. Indeed, in agreement with the NMR data, the CD spectra of the mixture samples vary substantially over time (Figure $3 \mathrm{H}$ ). This time-dependence is observed to a lesser extent for TDP-43 $3^{266-414}$ alone (Figure 3I) but not in hnRNP-A2 $288-341$ alone (Figure $3 \mathrm{~J}$ ). While changes in the CD spectra of the mixture sample start to appear after $4 \mathrm{~h}$ (Figure $3 \mathrm{H}$ ), the CD spectra of TDP-43 ${ }^{266-414}$ vary little over the first $7 \mathrm{~h}$ (Figure $3 \mathrm{I}$ ). The timescales of these changes in secondary structure correspond to those of the decreases in NMR signal.

Figure $4 \mathrm{~A}-\mathrm{D}$ show that the more hnRNP-A2 $288-341$ is added to TDP-43 ${ }^{266-414}$, the faster TDP-43 $3^{266-414}$ undergoes conformational change. The spectrum of TDP-43266-414 alone recorded after $22 \mathrm{~h}$ overlaps with those of 1:1, 1:3, and 1:5 mixtures with hnRNP-A2 ${ }^{288-341}$ recorded around nine, two and one hours, respectively. The same trends are observed in the time evolutions of the secondary structure contents of the proteins derived from CD measurements (Figures $3 \mathrm{H}, \mathrm{I}$ and $4 \mathrm{E}, \mathrm{H}$ ). The presence of an equal amount of hnRNP-A2 $2^{288-341}$ accelerates the decrease of the proportion of $\alpha$-helix and the increase in the proportion of antiparallel $\beta$-sheet. On the contrary, when hnRNP $\mathrm{A} 2^{288-341}$ is present in three- or five-fold excess, the conformational change is saturated right from the start, with very little $\alpha$-helix and similar proportions of antiparallel $\beta$-sheet at all incubation times (Figure 4G,H, supporting Table S1). 

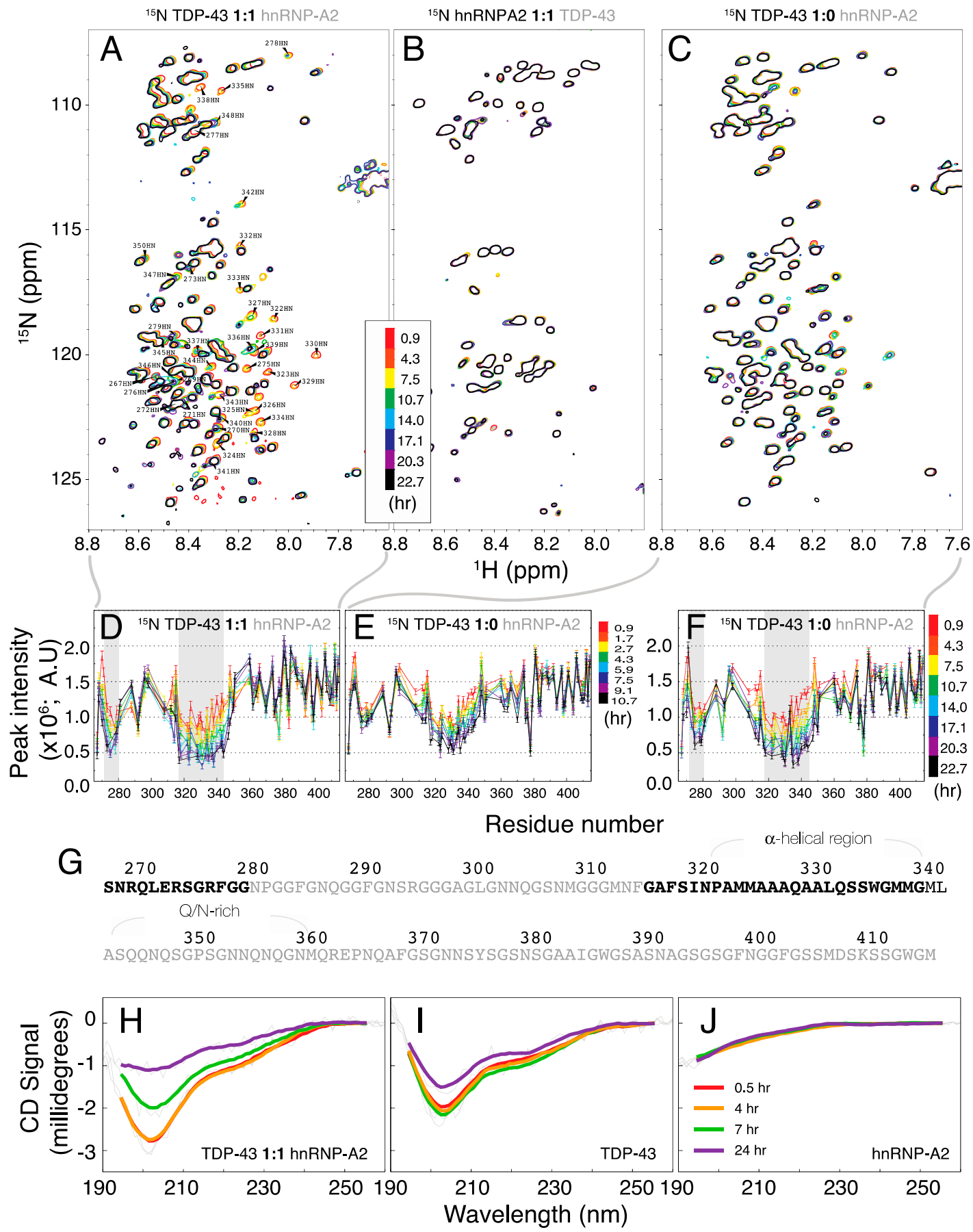

Figure 3. The time evolution of NMR HSQC and circular dichroism spectra indicates that conformational change in TDP-43 $266-414$ is accelerated by the presence of hnRNP-A2 ${ }^{288-341}$. (A-C) Time sequences of NMR HSQC spectra of ${ }^{15} \mathrm{~N}-\mathrm{TDP}-43$ (A) in the presence and (C) in the absence of hnRNP-A2 ${ }^{288-341}$, and (B) of ${ }^{15} \mathrm{~N}$ hnRNP-A2 $2^{288-341}$ in the presence of TDP-43 ${ }^{266-414}$. Assignments are shown for the cross-peaks whose position or intensity clearly change over time. (D-F) Time sequences of NMR peak intensity profiles as a function of residue number for (D) TDP-43 $3^{266-414}$ mixed with hnRNP-A2 $2^{288-341}$ and (E,F) for TDP-43 266-414 alone. (G) Primary sequence of TDP-43 $266-414$ with residues highlighted in black if the corresponding NMR intensity decreases over time. The $\alpha$-helical and $\mathrm{Q} / \mathrm{N}$ rich regions are also indicated. (H-J) Circular dichroism spectra at different incubation times of $(\mathbf{H})$ the mixture sample, (I) TDP-43 $3^{266-414}$ alone and (J) hnRNP-A2 ${ }^{288-341}$ only. 

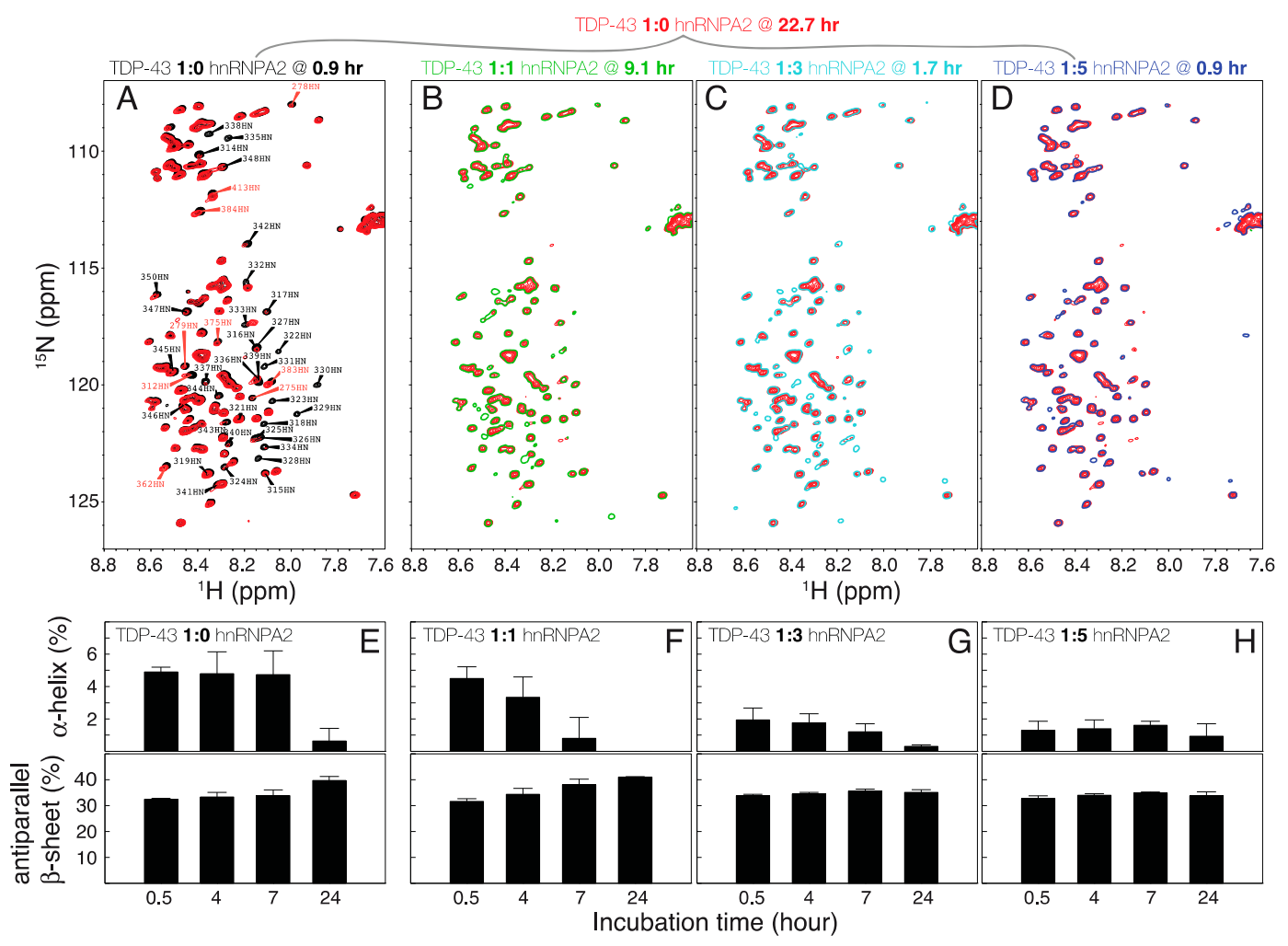

Figure 4. Increasing the amount of hnRNP-A2 $288-341$ accelerates transitions from $\alpha$-helix to $\beta$-sheet in TDP-43 266-414. (A-D) Comparisons of the NMR HSQC spectrum of TDP-43 $3^{266-414}$ in the absence of hnRNP-A2 ${ }^{288-341}$ after $22 \mathrm{~h}$ of incubation (red) with the spectra of (A) TDP-43 $266-414$ alone after $\sim 1 \mathrm{~h}$ incubation (black), (B) a 1:1 mixture of TDP-43 $266-414$ and hnRNP-A2 $2^{288-341}$ after $\sim 9$ h of incubation, (C) a 1:3 mixture of TDP-43 $266-414$ and hnRNP-A2 $2^{288-341}$ after $\sim 3$ h of incubation, and (D) a 1:5 mixture of TDP-43 $3^{266-414}$ and hnRNP-A2 ${ }^{288-341}$ after less than $1 \mathrm{~h}$ of incubation. (E-H) Proportions of secondary structure elements derived from CD measurements (upper panel: $\alpha$-helix; lower panel: antiparallel $\beta$-sheet) for the same mixtures at different incubation times.

The transient and dynamic nature of the $\alpha$-helical region of TDP-43 is known from previous solution NMR studies [37,39]. Detailed structural information on fibrillized TDP-43 has been obtained by X-ray crystallography for two peptide fragments (residues 321-326 and 333-343) which form an amyloid fibril with antiparallel $\beta$-sheets [43]. Cryo-EM images of the amyloid core of TDP-43 covering residues 311-360 are in agreement with the loss of the $\alpha$-helical component observed here [44]. Although the intrinsic $\alpha$-to- $\beta$ transition propensity of TDP- 43 has been suggested previously by studies of peptides (residues 311-360) [45,46], the present study demonstrates that this transition is accelerated in the presence of its interacting partner hnRNP-A2 (Figure 5). The monomeric IDR of TDP-43 populates both helix and coil conformations at equilibrium and tends to aggregate in its coil form. When the $\alpha$-helical region weakly contacts the IDR of hnRNP-A2, the coil population of TDP-43 is increased, which enhances its tendency to aggregate. Although the TDP-43 fibrillization or aggregation could be initiated by many factors, including the truncated RNA-recognition motifs (RRMs) [47], the interaction of the N-terminal domain [48,49], and the level of phosphorylation [50], our study using the IDRs of TDP-43 and hnRNP-A2, demonstrates another factor that also regulates TDP-43 aggregation. Our results may provide clues as to how these two proteins interact in their intact forms, in addition to their RNA-interacting domains. 


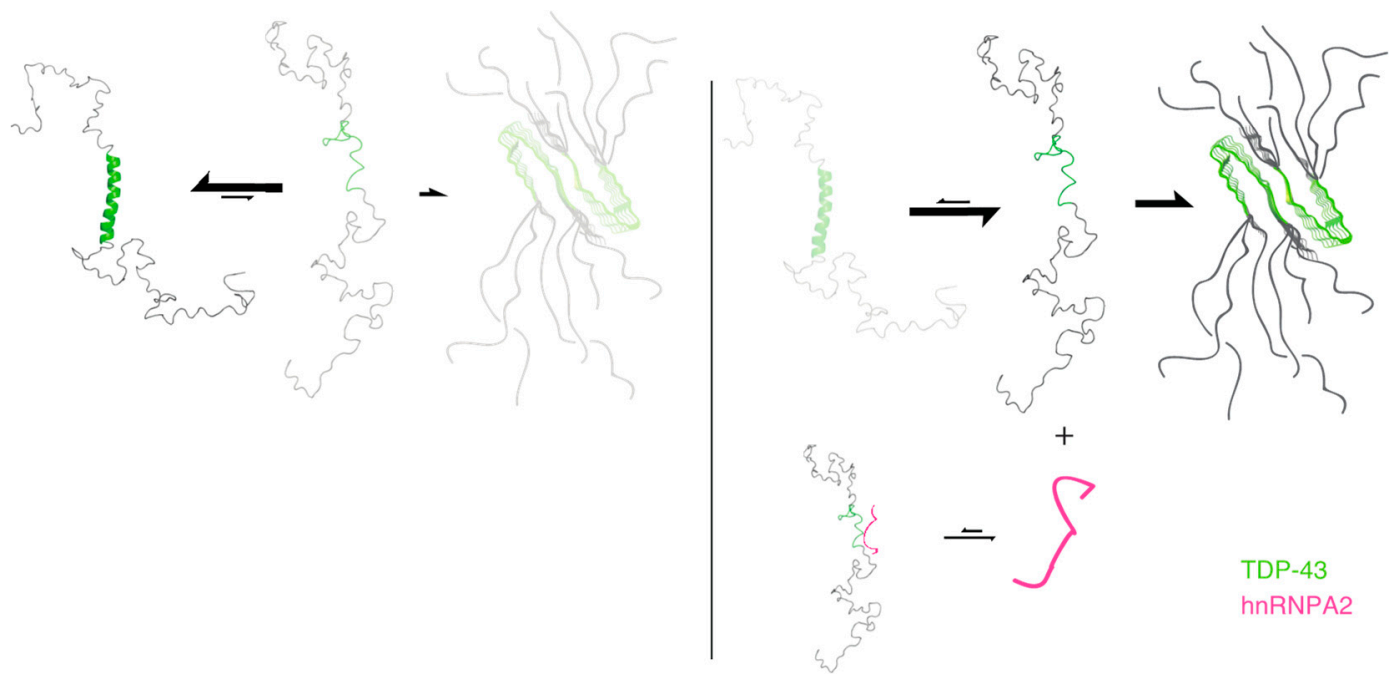

Figure 5. A schematic illustration of the proposed model. In the absence of hnRNP-A2, the IDR of TDP-43 is in equilibrium with both $\alpha$-helix and coil conformations but tends to aggregate in its coil form (left panel). When the $\alpha$-helical region of TDP-43's IDR weakly contacts the IDR of hnRNP-A2 (pink), the coil population of TDP-43 is increased, which enhances its tendency to aggregate (right panel).

\section{Materials and Methods}

\subsection{DNA Constructs}

The design of the TDP-43 ${ }^{266-414}$ construct has been described previously [37,51]. The cDNA of hnRNP-A2 was provided by Dr. Joseph J-T Huang (Academia Sinica). The cDNA corresponding to residues 288-341 was fused with hexahistidine-tagged SUMO protein at its $\mathrm{N}$-terminal domain to assist purification $\left(\mathrm{His}_{6}-\mathrm{SUMO}-\mathrm{hnRNPA}{ }^{228-341}\right)$ [52]. All constructs were fully sequenced.

\subsection{Protein Expression and Purification}

All proteins were expressed in Escherichia coli BL21 (DE3). The protocol used to express TDP-43 $3^{266-414}$ and hnRNP-A2 ${ }^{288-341}$ has been described in detail previously $[51,53]$. Briefly, overexpressed TDP-43 $3^{266-414}$ was purified from inclusion bodies dissolved by $8 \mathrm{M}$ urea. An IMAC (immobilized metal-ion affinity chromatography) nickel-charged (Qiagen, Inc., Hilde, Germany) column was used to purify the hexahistidine-tagged protein. The eluted sample then was purified using a C4 reverse phase column (Thermo Scientific, Inc., MA, USA) from an HPLC system. The purified sample was lyophilized for storage. For every experiment, the lyophilized sample was dissolved in $10 \mathrm{mM}$ phosphate buffer at pH 6.5 with protease inhibitor (Roche, Inc., Basel, Switzerland). The protein concentration was determined using the Beer-Lambert law by measuring the absorbance at $280 \mathrm{~nm}$ with a NanoDrop UV-VIS spectrometer (Thermo Scientific, Inc.).

In the case of hnRNP-A2 $2^{288-341}$, the cell lysate supernatant was filtered $(0.45 \mu \mathrm{m})$ and loaded onto an IMAC column. Ten column volumes (CVs) of $50 \mathrm{mM}$ Tris- $\mathrm{HCl}$ with $300 \mathrm{mM} \mathrm{NaCl}$ at $\mathrm{pH}$ 7.5 were applied to wash the column. The target protein was eluted using five CVs of washing buffer with $500 \mathrm{mM}$ imidazole. A PD-10 column (GE Healthcare, Inc., Chicago, IL, USA) was applied to remove imidazole. A final concentration of $1 \mathrm{mg} / \mathrm{mL} 6 \times$ His-Ulp $1^{403-621}$ protease was added to the protein solution and left at $4{ }^{\circ} \mathrm{C}$ for $2 \mathrm{~h}$ to detach the $6 x \mathrm{His}-\mathrm{SUMO}$ tag from hnRNP-A2 $2^{288-341}$. The protease-digested solution was loaded onto a nickel-charged IMAC column and the flow-through was collected. The purified protein was buffer exchanged to $10 \mathrm{mM}$ phosphate buffer at $\mathrm{pH} 6.5 \mathrm{using}$ a PD-10 column. Protein purity was verified using SDS-PAGE (an example is shown in the Supporting Information, Figure S1. The purified sample was frozen with liquid nitrogen and stored at $-80^{\circ} \mathrm{C}$ until needed. 


\subsection{NMR Spectroscopy and Data Analysis}

${ }^{15} \mathrm{~N}$-edited HSQC spectra were recorded using the standard pulse sequence with WATERGATE solvent suppression $[54,55]$. Peak intensities were measured by fitting the data automatically using non-linear lineshapes [56]. All the HSQC spectra were recorded using a Bruker AVIII $600 \mathrm{MHz}$ spectrometer with a cryogenic probe at $288 \mathrm{~K}$, unless otherwise stated. The data were processed using NMRPipe [56], and peak intensities were obtained using NMRPipe's non-linear line shape modelling function, including a Lorenz-to-Gauss window function.

\subsection{Circular Dichroism Spectroscopy}

An AVIV model 410 spectropolarimeter was used to collect the circular dichroism spectra. All samples were loaded in a $0.1 \mathrm{~mm}$ cuvette. Data were collected and co-added with ten measurements for each data point between $190 \mathrm{~nm}$ and $260 \mathrm{~nm}$ with an interval of $1 \mathrm{~nm}$. All spectra were recorded at $288 \mathrm{~K}$ and the samples were kept in a water bath at $288 \mathrm{~K}$ between measurements. All experiments were performed in triplicate. The CD signal was normalized to the sample concentration and the number of residues. The measured theta machine units $(\theta)$ were converted to $\Delta \varepsilon$ using the following equation [57]:

$$
\Delta \varepsilon=\theta \times \frac{0.1 \times M R W}{l \times C \times 3298}
$$

where $l$ is the path length (in $\mathrm{cm}$ ), $C$ is the protein concentration (in $\mathrm{mg} / \mathrm{mL}$ ), and $M R W$ is the mean residue weight (molecular weight/residue number, in Daltons). The secondary structure populations were estimated using the program BeStSel [41,42]. All measurements were performed in triplicate.

\section{Conclusions}

Our study demonstrates that the presence of the IDR of hnRNP-A2 accelerates the disease-related $\alpha$-helix-to- $\beta$-sheet transition of the IDR of TDP-43 with residue-specific detail. This is an example of how IDRs affect each other's behavior and could be more generally applicable to other RBPs. More than 1500 RBPs are present in human cells and most of them have IDRs. In addition to the structured RNA-recognition motifs, our study demonstrates a general mechanism through which RBPs may regulate each other's functions through IDRs in RBP-mediated gene regulation.

Supplementary Materials: Supplementary materials can be found at http://www.mdpi.com/1422-0067/21/ 16/5930/s1. Figure S1: The SDS-PAGE showing different stages of the purification of hnRNP-A2288-341. M: protein size marker; BI/AI: before/after IPTG induction; S/P: supernatant/pellet of the lysed cell; F/W/E: flow-through/wash-through/elution of the first IMAC purification; Bd/Ad: before/after enzyme digestion; Fl2: second flow though the IMAC column. The purified hnRNP-A2288-341 is indicated with the red box. Table S1: The secondary structure population (\%) derived from CD measurement using BeStSel.

Author Contributions: J.-r.H.: conceptualization; W.-C.C., M.-H.L., T.-C.C., J.-r.H.: formal analysis; J.-r.H.: funding acquisition; W.-C.C., M.-H.L., T.-C.C., J.-r.H.: investigation; J.-r.H.: project administration; J.-r.H.: resources; T.-C.C., J.-r.H.: supervision; J.-r.H.: validation; J.-r.H.: writing-original draft; J.-r.H.: writing—review and editing. All authors have read and agreed to the published version of the manuscript.

Funding: Ministry of Science and Technology of Taiwan, grant numbers 106-2113-M-010-005-MY2, 108-2113-M-010-005, and 109-2113-M-010-003 to J.-r.H.

Acknowledgments: The authors thank the Academia Sinica High-Field NMR Center (HFNMRC) for technical support. (HFNMRC is funded by Academia Sinica Core Facility and Innovative Instrument Project (AS-CFII-108-112)).

Conflicts of Interest: The authors declare no conflict of interest. 


\section{Abbreviations}

$\begin{array}{ll}\text { NMR } & \text { Nuclear magnetic resonance } \\ \text { IDR } & \text { Intrinsically disordered regions } \\ \text { RBP } & \text { RNA binding protein } \\ \text { CD } & \text { Circular dichroism } \\ \text { TDP-43 } & \text { Tar DNA binding protein of } 43 \mathrm{kDa} \\ \text { hnRNP-A2 } & \text { Heterogeneous nuclear ribonucleoprotein A2 }\end{array}$

\section{References}

1. Stelzl, U.; Worm, U.; Lalowski, M.; Haenig, C.; Brembeck, F.H.; Goehler, H.; Stroedicke, M.; Zenkner, M.; Schoenherr, A.; Koeppen, S.; et al. A Human Protein-Protein Interaction Network: A Resource for Annotating the Proteome. Cell 2005, 122, 957-968. [CrossRef] [PubMed]

2. Shi, Y. A Glimpse of Structural Biology Through X-Ray Crystallography. Cell 2014, 159, 995-1014. [CrossRef] [PubMed]

3. Puthenveetil, R.; Vinogradova, O. Solution NMR: A powerful tool for structural and functional studies of membrane proteins in reconstituted environments. J. Biol. Chem. 2019, 294, 15914-15931. [CrossRef] [PubMed]

4. Simon, B.; Madl, T.; Mackereth, C.D.; Nilges, M.; Sattler, M. An efficient protocol for NMR-spectroscopy-based structure determination of protein complexes in solution. Angew. Chem. Int. Ed. 2010, 49, 1967-1970. [CrossRef]

5. Dubochet, J. On the Development of Electron Cryo-Microscopy (Nobel Lecture). Angew. Chem. Int. Ed. 2018, 57, 10842-10846. [CrossRef]

6. Henderson, R. From Electron Crystallography to Single Particle CryoEM (Nobel Lecture). Angew. Chem. Int. Ed. 2018, 57, 10804-10825. [CrossRef]

7. Frank, J. Single-Particle Reconstruction of Biological Molecules-Story in a Sample (Nobel Lecture). Angew. Chem. Int. Ed. 2018, 57, 10826-10841. [CrossRef]

8. Fernández-Leiro, R.; Scheres, S.H. Unravelling biological macromolecules with cryo-electron microscopy. Nature 2016, 537, 339-346. [CrossRef]

9. Uversky, V.N.; Dunker, A.K. Understanding protein non-folding. Biochim. Biophys. Acta BBA Proteins Proteom. 2010, 1804, 1231-1264. [CrossRef]

10. Bhowmick, A.; Brookes, D.H.; Yost, S.R.; Dyson, H.J.; Forman-Kay, J.D.; Gunter, D.; Head-Gordon, M.; Hura, G.L.; Pande, V.S.; Wemmer, D.E.; et al. Finding Our Way in the Dark Proteome. J. Am. Chem. Soc. 2016, 138, 9730-9742. [CrossRef]

11. Sugase, K.; Dyson, H.J.; Wright, P.E. Mechanism of coupled folding and binding of an intrinsically disordered protein. Nature 2007, 447, 1021-1025. [CrossRef] [PubMed]

12. Schneider, R.; Maurin, D.; Communie, G.; Kragelj, J.; Hansen, D.F.; Ruigrok, R.; Jensen, M.R.; Blackledge, M. Visualizing the Molecular Recognition Trajectory of an Intrinsically Disordered Protein Using Multinuclear Relaxation Dispersion NMR. J. Am. Chem. Soc. 2015, 137, 1220-1229. [CrossRef] [PubMed]

13. Delaforge, E.; Kragelj, J.; Tengo, L.; Palencia, A.; Milles, S.; Bouvignies, G.; Salvi, N.; Blackledge, M.; Jensen, M.R. Deciphering the Dynamic Interaction Profile of an Intrinsically Disordered Protein by NMR Exchange Spectroscopy. J. Am. Chem. Soc. 2018, 140, 1148-1158. [CrossRef] [PubMed]

14. Bozoky, Z.; Krzeminski, M.; Muhandiram, R.; Birtley, J.R.; Al-Zahrani, A.; Thomas, P.J.; Frizzell, R.A.; Ford, R.C.; Forman-Kay, J.D. Regulatory R region of the CFTR chloride channel is a dynamic integrator of phospho-dependent intra- and intermolecular interactions. Proc. Natl. Acad. Sci. USA 2013, 110, E4427-E4436. [CrossRef]

15. Sharma, R.; Raduly, Z.; Miskei, M.; Fuxreiter, M. Fuzzy complexes: Specific binding without complete folding. FEBS Lett. 2015, 589, 2533-2542. [CrossRef]

16. Borgia, A.; Borgia, M.B.; Bugge, K.; Kissling, V.M.; Heidarsson, P.O.; Fernandes, C.B.; Sottini, A.; Soranno, A.; Buholzer, K.J.; Nettels, D.; et al. Extreme disorder in an ultrahigh-affinity protein complex. Nature 2018, 555, 61-66. [CrossRef]

17. Wu, S.; Wang, D.; Liu, J.; Feng, Y.; Weng, J.; Li, Y.; Gao, X.; Liu, J.; Wang, W. The Dynamic Multisite Interactions between Two Intrinsically Disordered Proteins. Angew. Chem. Int. Ed. 2017, 56, 7515-7519. [CrossRef] 
18. Holmstrom, E.D.; Liu, Z.; Nettels, D.; Best, R.B.; Schuler, B. Disordered RNA chaperones can enhance nucleic acid folding via local charge screening. Nat. Commun. 2019, 10, 2453. [CrossRef]

19. Varadi, M.; Zsolyomi, F.; Guharoy, M.; Tompa, P. Functional Advantages of Conserved Intrinsic Disorder in RNA-Binding Proteins. PLoS ONE 2015, 10, e139731. [CrossRef]

20. Järvelin, A.I.; Noerenberg, M.; Davis, I.; Castello, A. The new (dis)order in RNA regulation. Cell Commun. Signal. 2016, 14, 9. [CrossRef]

21. Zagrovic, B.; Bartonek, L.; Polyansky, A.A. RNA-protein interactions in an unstructured context. FEBS Lett. 2018, 592, 2901-2916. [CrossRef] [PubMed]

22. Tsang, B.; Arsenault, J.; Vernon, R.M.; Lin, H.; Sonenberg, N.; Wang, L.Y.; Bah, A.; Forman-Kay, J.D. Phosphoregulated FMRP phase separation models activity-dependent translation through bidirectional control of mRNA granule formation. Proc. Natl. Acad. Sci. USA 2019, 116, 4218-4227. [CrossRef] [PubMed]

23. Patel, A.; Lee, H.O.; Jawerth, L.; Maharana, S.; Jahnel, M.; Hein, M.Y.; Stoynov, S.; Mahamid, J.; Saha, S.; Franzmann, T.M.; et al. A Liquid-to-Solid Phase Transition of the ALS Protein FUS Accelerated by Disease Mutation. Cell 2015, 162, 1066-1077. [CrossRef] [PubMed]

24. Molliex, A.; Temirov, J.; Lee, J.; Coughlin, M.; Kanagaraj, A.P.; Kim, H.J.; Mittag, T.; Taylor, P.J. Phase separation by low complexity domains promotes stress granule assembly and drives pathological fibrillization. Cell 2015, 163, 123-133. [CrossRef]

25. Vogler, T.O.; Wheeler, J.R.; Nguyen, E.D.; Hughes, M.P.; Britson, K.A.; Lester, E.; Rao, B.; Betta, N.D.; Whitney, O.; Ewachiw, T.E.; et al. TDP-43 and RNA form amyloid-like myo-granules in regenerating muscle. Nature 2018, 563, 508-513. [CrossRef]

26. Lin, Y.; Protter, D.S.W.; Rosen, M.K.; Parker, R. Formation and Maturation of Phase-Separated Liquid Droplets by RNA-Binding Proteins. Mol. Cell 2015, 60, 208-219. [CrossRef]

27. Qamar, S.; Wang, G.Z.; Randle, S.J.; Ruggeri, F.S.; Varela, J.A.; Lin, J.Q.; Phillips, E.C.; Miyashita, A.; Williams, D.; Ströhl, F.; et al. FUS Phase Separation Is Modulated by a Molecular Chaperone and Methylation of Arginine Cation-pi Interactions. Cell 2018, 173, 720-734. [CrossRef]

28. Hofweber, M.; Hutten, S.; Bourgeois, B.; Spreitzer, E.; Niedner-Boblenz, A.; Schifferer, M.; Ruepp, M.D.; Simons, M.; Niessing, D.; Madl, T.; et al. Phase Separation of FUS Is Suppressed by its Nuclear Import Receptor and Arginine Methylation. Cell 2018, 173, 706-719. [CrossRef]

29. Kim, T.H.; Tsang, B.; Vernon, R.M.; Sonenberg, N.; Kay, L.E.; Forman-Kay, J.D. Phospho-dependent phase separation of FMRP and CAPRIN1 recapitulates regulation of translation and deadenylation. Science 2019, 365, 825-829. [CrossRef]

30. Fang, X.; Wang, L.; Ishikawa, R.; Li, Y.; Fiedler, M.; Liu, F.; Calder, G.; Rowan, B.; Weigel, D.; Li, P.; et al. Arabidopsis FLL2 promotes liquid-liquid phase separation of polyadenylation complexes. Nature 2019, 569, 265-269. [CrossRef]

31. Ying, Y.; Wang, X.J.; Vuong, C.K.; Lin, C.H.; Damianov, A.; Black, D.L. Splicing Activation by Rbfox Requires Self-Aggregation through its Tyrosine-Rich Domain. Cell 2017, 170, 312-323. [CrossRef] [PubMed]

32. Gerstberger, S.; Hafner, M.; Tuschl, T. A census of human RNA-binding proteins. Nat. Rev. Genet. 2014, 15, 829-845. [CrossRef] [PubMed]

33. Buratti, E.; Brindisi, A.; Giombi, M.; Tisminetzky, S.; Ayala, Y.M.; Baralle, F.E. TDP-43 Binds Heterogeneous Nuclear Ribonucleoprotein A/B through its C-terminal Tail: An important region for the inhibition of cystic fibrosis transmembrane conductance regulator exon 9 splicing. J. Biol. Chem. 2005, 280, 37572-37584. [CrossRef] [PubMed]

34. D’Ambrogio, A.; Buratti, E.; Stuani, C.; Guarnaccia, C.; Romano, M.; Ayala, Y.M.; Baralle, F. Functional mapping of the interaction between TDP-43 and hnRNP A2 in vivo. Nucleic Acids Res. 2009, 37, 4116-4126. [CrossRef]

35. Budini, M.; Buratti, E.; Stuani, C.; Guarnaccia, C.; Romano, V.; De Conti, L.; Baralle, F. Cellular Model of TAR DNA-binding Protein 43 (TDP-43) Aggregation Based on its C-terminal Gln/Asn-rich Region. J. Biol. Chem. 2012, 287, 7512-7525. [CrossRef] [PubMed]

36. Obradovic, Z.; Peng, K.; Vucetic, S.; Radivojac, P.; Dunker, A.K. Exploiting heterogeneous sequence properties improves prediction of protein disorder. Proteins Struct. Funct. Bioinform. 2005, 61 (Suppl. 7), 176-182. [CrossRef] 
37. Li, H.R.; Chen, T.C.; Hsiao, C.L.; Shi, L.; Chou, C.Y.; Huang, J.R. The physical forces mediating self-association and phase-separation in the C-terminal domain of TDP-43. Biochim. Biophys. Acta BBA Proteins Proteom. 2018, 1866, 214-223. [CrossRef] [PubMed]

38. Li, H.R.; Chiang, W.C.; Chou, P.C.; Wang, W.J.; Huang, J.R. TAR DNA-binding protein 43 (TDP-43) liquid-liquid phase separation is mediated by just a few aromatic residues. J. Biol. Chem. 2018, 293, 6090-6098. [CrossRef]

39. Conicella, A.E.; Zerze, G.H.; Mittal, J.; Fawzi, N.L. ALS Mutations Disrupt Phase Separation Mediated by $\alpha$-Helical Structure in the TDP-43 Low-Complexity C-Terminal Domain. Structure 2016, 24, 1537-1549. [CrossRef]

40. Ryan, V.H.; Dignon, G.L.; Zerze, G.H.; Chabata, C.V.; Silva, R.; Conicella, A.E.; Amaya, J.; Burke, K.A.; Mittal, J.; Fawzi, N.L. Mechanistic View of hnRNPA2 Low-Complexity Domain Structure, Interactions, and Phase Separation Altered by Mutation and Arginine Methylation. Mol. Cell 2018, 69, 465-479. [CrossRef]

41. Micsonai, A.; Wien, F.; Bulyáki, É.; Kun, J.; Moussong, É.; Lee, Y.H.; Goto, Y.; Réfrégiers, M.; Kardos, J. BeStSel: A web server for accurate protein secondary structure prediction and fold recognition from the circular dichroism spectra. Nucleic Acids Res. 2018, 46, W315-W322. [CrossRef] [PubMed]

42. Micsonai, A.; Wien, F.; Kernya, L.; Lee, Y.H.; Goto, Y.; Réfrégiers, M.; Kardos, J. Accurate secondary structure prediction and fold recognition for circular dichroism spectroscopy. Proc. Natl. Acad. Sci. USA 2015, 112, E3095-E3103. [CrossRef] [PubMed]

43. Guenther, E.L.; Cao, Q.; Trinh, H.; Lu, J.; Sawaya, M.R.; Cascio, D.; Boyer, D.R.; Rodriguez, J.A.; Hughes, M.P.; Eisenberg, D. Atomic structures of TDP-43 LCD segments and insights into reversible or pathogenic aggregation. Nat. Struct. Mol. Biol. 2018, 25, 463-471. [CrossRef] [PubMed]

44. Cao, Q.; Boyer, D.R.; Sawaya, M.R.; Ge, P.; Eisenberg, D. Cryo-EM structures of four polymorphic TDP-43 amyloid cores. Nat. Struct. Mol. Biol. 2019, 26, 619-627. [CrossRef]

45. Jiang, L.L.; Che, M.X.; Zhao, J.; Zhou, C.J.; Xie, M.Y.; Li, H.Y.; He, J.H.; Hu, H.Y. Structural Transformation of the Amyloidogenic Core Region of TDP-43 Protein Initiates its Aggregation and Cytoplasmic Inclusion. J. Biol. Chem. 2013, 288, 19614-19624. [CrossRef]

46. Zhuo, X.F.; Wang, J.; Zhang, J.; Jiang, L.L.; Hu, H.Y.; Lu, J. Solid-State NMR Reveals the Structural Transformation of the TDP-43 Amyloidogenic Region upon Fibrillation. J. Am. Chem. Soc. 2020, 142, 3412-3421. [CrossRef]

47. Wang, Y.T.; Kuo, P.H.; Chiang, C.H.; Liang, J.R.; Chen, Y.R.; Wang, S.; Shen, J.C.K.; Yuan, H.S. The Truncated C-terminal RNA Recognition Motif of TDP-43 Protein Plays a Key Role in Forming Proteinaceous Aggregates. J. Biol. Chem. 2013, 288, 9049-9057. [CrossRef]

48. Chang, C.K.; Wu, T.H.; Wu, C.Y.; Chiang, M.H.; Toh, E.K.W.; Hsu, Y.C.; Lin, K.F.; Liao, Y.H.; Huang, T.H.; Huang, J.J.T. The N-terminus of TDP-43 promotes its oligomerization and enhances DNA binding affinity. Biochem. Biophys. Res. Commun. 2012, 425, 219-224. [CrossRef]

49. Romano, V.; Quadri, Z.; Baralle, F.E.; Buratti, E. The structural integrity of TDP-43 N-terminus is required for efficient aggregate entrapment and consequent loss of protein function. Prion 2015, 9, 1-9. [CrossRef]

50. Neumann, M.; Kwong, L.K.; Lee, E.B.; Kremmer, E.; Flatley, A.; Xu, Y.; Forman, M.; Troost, D.; Kretzschmar, H.A.; Trojanowski, J.Q.; et al. Phosphorylation of S409/410 of TDP-43 is a consistent feature in all sporadic and familial forms of TDP-43 proteinopathies. Acta Neuropathol. 2009, 117, 137-149. [CrossRef]

51. Chen, T.C.; Hsiao, C.L.; Huang, S.J.; Huang, J.R. The Nearest-Neighbor Effect on Random-Coil NMR Chemical Shifts Demonstrated Using a Low-Complexity Amino-Acid Sequence. Protein Pept. Lett. 2016, 23, 967-975. [CrossRef] [PubMed]

52. Lee, C.D.; Sun, H.C.; Hu, S.M.; Chiu, C.F.; Homhuan, A.; Liang, S.M.; Leng, C.H.; Wang, T.F. An improved SUMO fusion protein system for effective production of native proteins. Protein Sci. 2008, 17, 1241-1248. [CrossRef] [PubMed]

53. Lin, Y.H.; Qiu, D.C.; Chang, W.H.; Yeh, Y.Q.; Jeng, U.S.; Liu, F.T.; Huang, J.R. The intrinsically disordered $\mathrm{N}$-terminal domain of galectin-3 dynamically mediates multisite self-association of the protein through fuzzy interactions. J. Biol. Chem. 2017, 292, 17845-17856. [CrossRef] [PubMed]

54. Piotto, M.; Saudek, V.; Sklenár, V. Gradient-tailored excitation for single-quantum NMR spectroscopy of aqueous solutions. J. Biomol. NMR 1992, 2, 661-665. [CrossRef]

55. Bodenhausen, G.; Ruben, D.J. Natural abundance N-15 NMR by enhanced heteronuclear spectroscopy. Chem. Phys. Lett. 1980, 69, 185-189. [CrossRef] 
56. Delaglio, F.; Grzesiek, S.; Vuister, G.W.; Zhu, G.; Pfeifer, J.; Bax, A. NMRPipe: A multidimensional spectral processing system based on UNIX pipes. J. Biomol. NMR 1995, 6, 277-293. [CrossRef]

57. Greenfield, N.J. Using circular dichroism spectra to estimate protein secondary structure. Nat. Protoc. 2006, 1, 2876-2890. [CrossRef]

(C) 2020 by the authors. Licensee MDPI, Basel, Switzerland. This article is an open access article distributed under the terms and conditions of the Creative Commons Attribution (CC BY) license (http://creativecommons.org/licenses/by/4.0/). 